\title{
"Evaluation of access to finance, market and viability of small and medium-sized enterprises in South Africa"
}

\begin{tabular}{|c|c|}
\hline AUTHORS & $\begin{array}{l}\text { Thabiso Msomi } \text { https://orcid.org/0000-0003-3941-6815 } \\
\text { Odunayo Olarewaju (D https://orcid.org/0000-0002-4366-040X } \\
\text { R https://publons.com/researcher/AAU-1024-2020 }\end{array}$ \\
\hline ARTICLE INFO & $\begin{array}{l}\text { Thabiso Msomi and Odunayo Olarewaju (2021). Evaluation of access to finance, } \\
\text { market and viability of small and medium-sized enterprises in South Africa. } \\
\text { Problems and Perspectives in Management, 19(1), 281-289. } \\
\text { doi:10.21511/ppm.19(1).2021.24 }\end{array}$ \\
\hline DOI & http://dx.doi.org/10.21511/ppm.19(1).2021.24 \\
\hline RELEASED ON & Monday, 15 March 2021 \\
\hline RECEIVED ON & Sunday, 20 December 2020 \\
\hline ACCEPTED ON & Thursday, 18 February 2021 \\
\hline LICENSE & $\begin{array}{l}(c)) E Y \\
\text { This work is licensed under a Creative Commons Attribution } 4.0 \text { International } \\
\text { License }\end{array}$ \\
\hline JOURNAL & "Problems and Perspectives in Management" \\
\hline ISSN PRINT & $1727-7051$ \\
\hline ISSN ONLINE & $1810-5467$ \\
\hline PUBLISHER & LLC "Consulting Publishing Company "Business Perspectives" \\
\hline FOUNDER & LLC "Consulting Publishing Company "Business Perspectives" \\
\hline
\end{tabular}

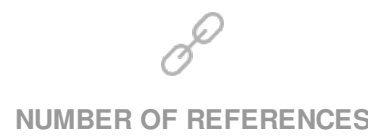

38
NUMBER OF FIGURES

0
NUMBER OF TABLES

2

(C) The author(s) 2023. This publication is an open access article. 


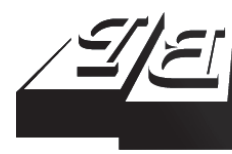

\section{BUSINESS PERSPECTIVES}

LLC "CPC "Business Perspectives" Hryhorii Skovoroda lane, 10, Sumy, 40022, Ukraine www.businessperspectives.org
Received on: $20^{\text {th }}$ of December, 2020 Accepted on: $18^{\text {th }}$ of February, 2021 Published on: $15^{\text {th }}$ of March, 2021

(c) Thabiso Msomi,

Odunayo Olarewaju, 2021

Thabiso Msomi, Postgraduate Student, Department of Management Accounting, Faculty of Accounting and Informatics, Durban University of Technology, South Africa.

Odunayo Olarewaju, Ph.D., Senior Lecturer, Department of Management Accounting, Faculty of Accounting and Informatics, Durban University of Technology, South Africa. (Corresponding author)
This is an Open Access article, distributed under the terms of the Creative Commons Attribution 4.0 International license, which permits unrestricted re-use, distribution, and reproduction in any medium, provided the original work is properly cited.

Conflict of interest statement: Author(s) reported no conflict of interest

\section{EVALUATION OF ACCESS TO FINANCE, MARKET AND VIABILITY OF SMALL AND MEDIUM-SIZED ENTERPRISES IN SOUTH AFRICA}

\begin{abstract}
Access to finance and market has been described as a predominant challenge confronting small and medium-sized enterprises (SMEs). Hence, this paper seeks to evaluate access to finance, market access and viability of SMEs. A quantitative research method and a purposive sampling technique were used to select the participants for this study. Respondents from retail, manufacturing, construction and agricultural SMEs operating in Durban, KwaZulu-Natal, were selected to complete the structured questionnaires. 310 questionnaires were returned out of 321 distributed. The study revealed a significant effect of access to finance (absolute value 0.425 ) and access to market (absolute vale 0.373 ) on SMEs' viability with a $5 \%$ level of significance. Thus, it was concluded that access to finance uniquely accounted for the larger proportion of the variance in the regression model. Thus, this study suggests that owners of SMEs should pay greater attention to access to finance in running their businesses, and the Government should aid SMEs to market their products and keep their businesses viable. Public loans or the government supported loans should be made available for SMEs with soften requirements in order to stimulate economic growth.
\end{abstract}

\section{Keywords financial viability, linear regression analysis, market penetration, external funding, business survival}

\section{JEL Classification $\quad$ D22, M20, M41}

\section{INTRODUCTION}

Accessibility of finance and the market for small and medium-sized enterprises (SMEs) has attracted the attention of economists and policy makers around the world for many decades (Connolly and Bank, 2020). Funding remains one of the problems facing the small business sector in South Africa. Worldwide, the downturn in economic growth has contributed to a decrease in the financing of small businesses. The global economy decreased from $3.4 \%$ to $3.0 \%$ in 2019 , which also impacted South Africa's economic growth productivity (International Monetary Fund, 2019). SMEs in South Africa have been addressing the issue of access to finance and the market in the form of conferences and other discussions to boost the financial line of SMEs and to formally incorporate their contributions into the economy (De la Torre et al., 2017). SMEs are the backbone of the national economy, offering the most employment and making a major contribution to the gross domestic product (GDP). To overcome South Africa's high unemployment rate and reduce poverty, a prosperous and welcoming climate must be developed to promote the survival and development of small businesses and ensure increased employment opportunities (Kimanzi \& Gamede, 2020). The financing of SMEs is a critical component of this development (Bruhn \& Love, 2014). Access to finance is one of the major hurdles for start-ups, micro, very small, small and medi- 
um-sized enterprises in the country, and one that needs immediate attention (Adegboye \& Iweriebor, 2018). This is because financing is a key element in determining the growth, sustainability and viability of SMEs. De la Torre et al. (2017) were of the view that external funding for SMEs is important to boost start-ups businesses. Without external funding, SMEs would find it difficult to participate on the global market, grow businesses and develop business ties with large businesses. In addition, access to finance, as well as the access to markets, is the greatest stumbling block to the expansion of enterprises and startups listed by established SMEs and prospective operators (Connolly \& Bank, 2020).

Small businesses often fail to meet the requirements for obtaining the necessary amount of debt financing for lengthier growth (Yeboah, 2020). Typical issues include a lack of sufficient collateral, substantial debt load and lack of developed business skills (Connolly \& Bank, 2020). For businessmen to receive an unsecured loan purely on the merit of their character, a significant leap of faith and trust of the borrower is required (Johnstone-Robertson, 2017). Typically, such unsecured credit comes only after a certain period of time has elapsed and against an established track record that one or more small business enterprise effectively runs on their own account (Yeboah, 2020). The financing of SMEs is highly reliant on owners and individuals close to them at the earliest stage of growth (Distinguin et al., 2016). As successful SMEs grow, sources of internal funding quickly arise and graduate to external capital, including venture capital, corporate investment, bank debt and venture capital (Adegboye \& Iweriebor, 2018).

The participation of SMEs in the social economic development of South Africa is of utmost importance and, thus, the reluctance to strengthen access to financing and market access for small enterprises will impede economic growth (Desta, 2015; De la Torre et al., 2017). Unfortunately, large companies can afford to use the services of professionals to handle their accounts, but SMEs cannot afford to serve skilled accountants, so identifying some key predictors to allow small and medium-sized business owners to develop and be viable is a significant part of this research paper. This paper seeks to supply general insight into the importance of the problem at hand in a developing country, given that limited research has been conducted on the same topic in South Africa. It will make a significant contribution to the subject as a new knowledge of the importance of access to finance and market access for the viability of SMEs in the world. To draw a conclusion of the study, it is necessary to improve the understanding of SMEs.

\section{LITERATURE REVIEW AND HYPOTHESIS DEVELOPMENT}

Financial access is important for SME growth (Bruhn \& Love, 2014). It enables entrepreneurs to innovate, increase productivity, grow to new markets and create millions of jobs (Kim et al., 2018). However, in developed countries, the large proportion of small and medium-sized companies are unable to access the funding they need to achieve their potential. The funding of small businesses in the developing world can be complex and costly for lenders. To mitigate the credit gap, governments, financial institutions and donors are investing in lending products and policies designed supply SMEs with the financing they need to expand and innovate (Rosavina et al., 2019). Even so, the degree to which such initiatives successfully eliminate obstacles to the funding of SMEs has typically not been intensively measured (Bruhn \& Love, 2014).

On the other hand, market segmentation means that there is no connection between demand for and the availability of financial services. Because of the risky and intertemporal nature of credit trading, knowledge requirements and lender compliance concerns are strong, resulting in agency costs impacting the outcome of SME-focused credit programmes (Hamburg \&O'Brien, 2014). As a result, businesses may consider funds from external sources, because of the high costs associated, they may not apply. While the total participation of companies in the stock sector may be minimal, smaller businesses have far less involvement than larger ones (Nassr \& Wehinger, 2016). 
The competitiveness of SMEs is characterised by financial viability (Humavindu \& Stage, 2015). Financial viability is when reasonably adequate sales are generated to meet operating costs and debt and continues to ensure growth while retaining the service level offered by SMEs (Ndione, 2020). Financial viability assessment is an important part of any business; however, small and medium-sized businesses do not have financial resources to employ the services of professional organizations to assess their financial viability (Koleda \& Oganisjana, 2015). These practitioners also provide advice on four main issues: liquidity, activity, leverage and profitability ratios (Smit et al., 2013), which indicate whether the SME will be viable or not.

The determination of financial viability includes the financial statement audit, the results report and the business plan (Registrar of Community Housing, 2010). The results of the evaluation shall decide the financial feasibility, the trends in company activities and projects for the future of SMEs (Li et al., 2016). However, SME owners may lack the requisite expertise on financial accounting to establish a template for collecting information on their day-to-day operations (Trivedi, 2019). Metrics for the SME's ability to provide adequate financial details are the extent to which the necessary information is provided and the clarification of financial variances, changes or events in the financial statements where the reports do not provide potential information on the SME's financial condition (Registrar of Community Housing, 2010).

While small enterprises still exist, their survivability is being threatened because of economic challenges. The start-up, maturity and success of small enterprises remain issues in this respect. Lekhanya (2015) argued that a good understanding of the principles of sustainability and development of SMEs is useful for job creation in South Africa. Despite these differences, economic and social theories should be associated with the theory of survival and development. For small and medium-sized businesses to succeed, a certain level of financial understanding and expertise is required (Li et al., 2016). SMEs should also consider their social dimension and patterns in order to tailor their goods and services to satisfy the needs of their clients.
Many multilateral institutions, such as the World Bank and many academics, openly acknowledge that the lack of access to affordable finance and markets restricts the growth of SMEs with a substantial gap in terms of both financial and market access by larger global enterprises (Ketterer, 2017). SMEs play an essential part in South Africa's economic growth. Access to financing and market access are crucial for the viability of SMEs (Rankhumise \& Letsoalo, 2019).

Al Mamun et al. (2018) have found that adolescents who have access to financial resources are more likely to become entrepreneurs. Torrès and Thurik (2019) are of the opinion that if the government wanted to increase the level of entrepreneurship, it had to build more financial support for limited-capital prospective entrepreneurs. Prior literature has also shown that youth have limited access to financial capital to start a business, which means that they have less time to generate the necessary funds and do not start their own business due to their financial limitations (Jovanovic, 2019).

Some empirical studies have shown that a lack of access to finance and financial system issues are seen by aspiring businessmen in developing countries as a major impediment (Rahaman et al., 2020). Access to capital can be more stringent than business options for developing countries with successful financial infrastructure because of high barriers to entry (Rahaman et al., 2020). Financial capital works similarly in social entrepreneurship to traditional companies. In this analysis, an evaluation of the individual's ability to locate, access and use capital efficiently was regarded in terms of access to finance. This can have a significant effect on social entrepreneurship purpose through a high degree of perceived access to finance.

In the UK, the availability of financing for SMEs is assumed to be closely influenced by variations in commercial banks or supply-side policies and practices. The point is that the ties between the credit institutions and the entrepreneur are different in most commercial banks in the UK (Esubalew \& Raghurama, 2020). Many factors limiting the access to finance for SMEs were identified by the World Bank (2003). These factors include financial sector inequalities, the lack of banking know-how, asymmetry of knowledge (accessing market infor- 
mation) and the significant risk of lending to small businesses.

Esubalew and Raghurama (2020) have described financial and legal vulnerabilities as an obstruction to accessing finance products in developing nations. When Beck (2007) studied 70 countries in the developing world, he reached the conclusion that it was ultimately up to the local government to create institutions. To have a proper regulatory structure to reduce the financial restrictions of SMEs, business practices should be carried out in a friendly way. Studies on the lack of collateral requirements, asymmetries in knowledge, high risk, small credit loans, especially in rural households, and the lender-borrowing gap have been the main reasons for credit differences among different and established credit sources (Jaabei, 2018; Mbowe et al., 2020). The same researchers also note that the policies and styles of financial agencies decide access to finance in one way or another.

Lekhanya (2015) explored the role of SMEs in economic development and indicated that little has been done to enhance the viability and growth of SMEs in South Africa. This is due to a lack of deep understanding from a policy standpoint and the lack of understanding among stakeholders on how to use SMEs to build the jobs required in the country. This study applied a quantitative analysis approach to the collection of primary data from four provinces of South Africa and 230 people engaged. The study found that most SMEs would fail within five years of their existence. The main explanation for this is a lack of access to funding, lack of management experience and human capital. In addition, the owners of small and medium-sized businesses do not have business management expertise, but rather are ordinary entrepreneurs.

The three main groups on access restriction for SMEs to financing have been established by Olomi et al. (2018). The first group of factors included: ability (low degree of skills and knowledge), underdeveloped market culture, business division between personal and familial problems, credit background of small and medium-sized businesses and lack of knowledge of the financial services available. Secondly, the number of skilled workers and the lack of expertise for SMEs. The third factor group relates to environmental regulation, where transactions take place between borrowers and lenders, the lack of system recognition and credit agencies.

Hence, the hypotheses for this study are stated as:

$H_{0}: \quad$ Access to finance and access to the market do not have an effect on the viability of SMEs in South Africa.

$H_{1}$ : Access to finance and access to the market have an effect on the viability of SMEs in South Africa.

\section{METHODOLOGY}

The study employed the descriptive survey design, which used the positivist paradigm. Based on the data obtained from a five-point Likert scale questionnaire, the quantitative aspect of the study was founded. The target population for the study includes 700 SMEs in KwaZulu-Natal. In research, the Cochran formula is adopted whenever the target population is unspecified or too large (Hoaglin, 2016). A modified version of the Cochran formula for evaluating sample size in small populations was adopted for this analysis. For this analysis, the sample size was 321 SMEs. SMEs came under the category that defines small enterprises according to the number of workers, the total gross assets and the overall total turnover range. Owners of small and medium-sized businesses or an appropriate representative of the SME owner in their enterprise have been chosen because the enterprise has between 10 and 200 employees. These SMEs include retail, manufacturing, construction and agriculture businesses that were chosen to evaluate access to finance, market access and viability of SMEs. To achieve the study objective, structured questionnaires were designed to collect primary data from SME respondents operating in Durban, in the province of KwaZulu-Natal. The emails were sent as part of the recruitment process and email addresses of the respondents were derived from their websites and from the online SEDA database. Each prospective participant listed in the Durban Chamber of Commerce and Industry (DCCI) catalogue was initially invited to participate via email. The SME respondents were sampled using a purposive sampling technique to allow the re- 
searchers to use their own judgment in order to select the appropriate representative of the business. A total of 321 questionnaires were administered to the respondents, 310 were returned and six of these were incorrectly completed and have been discarded. For this analysis, the remaining 304 , which represented $98 \%$ of the response rate, were coded and analyzed.

To evaluate the factor structures of the items used to calculate and of the constructs measured in this study, the Statistical Package for Social Sciences (SPSS) was used for data analysis through descriptive analysis, and regression analysis.

\section{DATA ANALYSIS AND DISCUSSION OF FINDINGS}

\subsection{Descriptive analysis: Access to finance for SMEs' viability}

The analysis in terms of Access to finance for SMEs' viability was neutral on the outcome as follows: financial services offered by the bank have led to an improvement in the business (38.2\%), financial services offered by the bank have enabled us to pay utility bills (35.9\%), saving product provided by the bank is suitable (43.4\%), loan product provided by the bank suits our needs (47.0\%), terms and conditions on bank loans are favorable (49.3\%), and lack of access to information on getting government support to grow the business (31.3\%). However, respondents agree as follows: financial services offered by the bank have improved our access to sophisticated technology (34.5\%), savings product offered by the bank is safe (44.1\%), financial services provided by the bank are safe $(34.9 \%)$, account opening fees charged by the bank are affordable $(37.5 \%)$, and cost of making a trip to the bank is affordable (41.4\%).

In terms of SMEs' access to the market, the respondents disagreed on the outcome: Government assists in marketing my product to keep my business viable (31.9\%), access to market is a challenge to my business (37.8\%), and owners have access to market the product of my business (48.7\%).

\subsection{Descriptive analysis of the survey respondents' answers on sources of finance for SMEs}

The outcome on the knowledge of established agencies to help SMEs grow is presented in Table 1, which shows the source of finance available for SMEs to carry out their business.

Table 1. Availability of the following source of finance for SMEs

\begin{tabular}{l|c:c}
\hline \multicolumn{1}{c|}{ Source of finance } & Frequency & Percent \\
\hline $\begin{array}{l}\text { Accelerated and shared growth } \\
\text { initiative for SA }\end{array}$ & 49 & 16.1 \\
\hline $\begin{array}{l}\text { Small Enterprise Development } \\
\text { Agency }\end{array}$ & 124 & 40.8 \\
\hline Khula Enterprise Finance Limited & 45 & 14.8 \\
\hline Small Enterprise Funding Agency & 40 & 13.2 \\
\hline National Empowerment Fund & 23 & 7.6 \\
\hdashline $\begin{array}{l}\text { Department of Small Business } \\
\text { Development }\end{array}$ & 23 & 7.6 \\
\hline Total & 304 & 100.0 \\
\hline
\end{tabular}

The output shows that $16.1 \%$ are aware of the available source of finance from accelerated and shared growth initiatives, $40.8 \%$ are aware of finance from the Small Enterprise Development Agency, $14.8 \%$ are aware of the available source of finance from Khula Enterprise Finance Limited, 13.2\%, $7.6 \%$, and $7.6 \%$ are aware of the available source of finance respectively from the Small Enterprise Funding Agency, National Empowerment Fund and Department of Small Business Development.

However, when respondents were asked whether they lack access to information on getting Government support to grow their business as indicated in terms of Access to Finance for SMEs' Viability, $8.9 \%$ of respondents strongly disagreed, $18.8 \%$ disagreed, $31.3 \%$ were neutral, $27.3 \%$ agreed, and $13.8 \%$ strongly agreed. This suggests that a high percentage $(31.3 \%)$ of respondents were neutral.

\subsection{Regression analysis of access to finance, market access and SMEs' viability}

The result shows that a linear regression analysis was conducted to establish the causal influence between the independent variables (i.e. access to market and access to finance) and the dependent 
Table 2. Output of regression analysis on access to the market and access to finance as predictors of SMEs' viability

\begin{tabular}{l|c|c|c|c|c|c|c|c}
\hline \multicolumn{1}{c|}{ Variables in the equation } & B & Beta & T & $p$-value & $R^{2}$ & F & df & $p$-value \\
\hline Constant & 6.424 & & 4.250 & $<0.0005$ & & & & \\
Access to finance & 0.425 & 0.444 & 8.788 & $<0.0005$ & 0.442 & 78.881 & $2 ; 299$ & $<0.0005$ \\
\hline Market access & 0.373 & 0.163 & 3.760 & $<0.0005$ & & & & \\
\hline
\end{tabular}

variable (DV) (i.e. SMEs' viability). Table 2 summarizes outputs from the regression analysis.

A. Predictor: (Constant), access to finance and access to the market

\section{B. DV: SMEs' viability}

The linear regression analysis was conducted to establish the relationship between the independent variables (i.e. access to market and access to finance) and the dependent variable (DV) (i.e. SMEs' viability). The outcome shows the regression model with three independent variables where access to finance has the largest absolute value 0.425 , which indicates the access to finance uniquely accounts for the larger proportion of the variance in the regression model. This is in line with Adegboye and Iweriebor (2018). The outcome of this study indicates that market access and access to finance are variables that influence SMEs' viability. However, it was noted that access to finance has the largest absolute value of 0.425 , thus accounting for the larger proportion of the variance in the regression model for this study. This implies that SMEs should not only focus on access to market in running their businesses but also on access to finance. It was discovered that access to finance and market access uniquely account for SMEs' viability. This revelation indicates that SMEs should consider finance access as a cogent factor to make their businesses viable.

\section{CONCLUSION}

Based on the summary of findings, the null hypothesis was rejected, and the study concludes that access to finance has the largest absolute value (0.425) which uniquely accounts for the largest proportion of the variance in the regression model. This suggests that SME owners and the government should pay greater attention to financial access in running their businesses. The government should aid SMEs to market their products and keep their businesses viable. The lack of preference to borrow from government agencies might suggest a lack of confidence in these agencies. Based on the findings of the study, it is recommended that access to finance policies should be set by governments to positively affect firms' employment, productivity and growth. The requirements to accessing loans should be softened enough to accommodate small business owners at all levels. SMEs' ability to obtain financial services, such as deposit, credit, insurance, payment and other risk management services, should be greatly supported. Government should ensure that no SMEs is unbanked or debanked.

The lack of financial access by SMEs limits the range of services that can be rendered by these enterprises. Most SME owners have been found to rely on their personal wealth and resources to invest in their businesses, which inadvertently limits their full potential. Thus, it leads to a cycle of tenacious disparity and reduced growth. It has been ascertained that financial access encourages enterprises' growth (small businesses included) via credit provision to both new and existing businesses. Also, this in turn benefits the economy by quickening economic growth, increasing demand for labor, as well as boosting competition. Access to finance also has the capacity to reduce poverty and income disparity by increasing the incomes of those in the lower end of the income hierarchy.

The only limitation of this study is that the responses were not categorized into the retail, construction, agriculture and manufacturing sectors, which poses a challenge in access to the market and issues that were specific to each sector. The study was limited in terms of finding the level of access to finance and 
access to the market needed by each sector of SMEs. The demographic information was not correlated with the responses from the various categories, namely the retail, construction, agriculture, and manufacturing sectors. Such correlation is recommended for future work.

Future study should focus on comparative analysis of the retail, manufacturing and agricultural sectors and other sectors within the SMEs to understand the influence of access to finance and market access on business viability.

\section{AUTHOR CONTRIBUTIONS}

Conceptualization: Thabiso Msomi.

Data curation: Thabiso Msomi.

Formal analysis: Thabiso Msomi, Odunayo Olarewaju.

Investigation: Thabiso Msomi.

Methodology: Odunayo Olarewaju.

Project administration: Thabiso Msomi.

Resources: Thabiso Msomi.

Software: Thabiso Msomi, Odunayo Olarewaju.

Supervision: Thabiso Msomi, Odunayo Olarewaju.

Validation: Thabiso Msomi.

Visualization: Thabiso Msomi.

Writing - original draft: Thabiso Msomi.

Writing - review \& editing: Odunayo Olarewaju.

\section{REFERENCE}

1. Abay, H. H., Temanu, F. G., \& Gebreegziabher, A. H. (2015). Owner factors affecting the growth of micro and small enterprises (MSES) in Ethiopia: A case study in Shire Indaselassie town, Tigray. Clear International Journal of Research in Commerce \& Management, 6(5), 66-72. Retrieved from https://www. semanticscholar.org/paper/OWNER-FACTORS-AFFECTINGTHE-GROWTH-OF-MICROAND-IN-Abay-Gebreegziabher/6 2da5123989202cdceda080a2b5115 c8b6245613

2. Adegboye, A. C., \& Iweriebor, S. (2018). Does access to finance enhance SME innovation and productivity in Nigeria? Evidence from the World Bank Enterprise Survey. African Development Review, 30(4), 449-461. https://doi. org/10.1111/1467-8268.12351

3. Al Mamun, A., Nawi, N. B. C., Ibrahim, M. A. H. B., \& Muniady, R. (2018). Effect of economic vulnerability on competitive advantages, enterprise performance and sustainability. Social Sciences, 7(4), 54. Retrieved from https://ideas.repec.org/a/ gam/jscscx/v7y2018i4p54d139396.html

4. Beck, T. (2007, April). Financing constraints of SMEs in developing countries: Evidence, determinants and solutions. In KDI 36th Anniversary International Conference (pp. 26-27). Retrieved from https://core.ac.uk/download/ pdf/6635804.pdf

5. Bhorat, H., Asmal, Z., Lilenstein, K., \& Van der Zee, K. (2018). SMMEs in South Africa: Understanding the constraints on growth and performance (Development Policy Research Unit Working Paper 201802). DPRU, University of Cape Town. Retrieved from https://media. africaportal.org/documents/ DPRU_WP201802.pdf

6. Björklund, M., Abrahamsson, M., \& Johansson, H. (2017). Critical factors for viable business models for urban consolidation centres.
Research in Transportation Economics, 64, 36-47. https://doi. org/10.1016/j.retrec.2017.09.009

7. Bruhn, M., \& Love, I. (2014). The real impact of improved access to finance: Evidence from Mexico. The Journal of Finance, 69(3), 1347-1376. https://doi. org/10.1111/jofi.12091

8. Connolly, E., \& Bank, J. (2020). Access to small business finance. RBA Bulletin. Retrieved from https://www.rba.gov.au/publications/bulletin/2018/sep/access-tosmall-business-finance.html

9. De la Torre, A., Gozzi, J. C., \& Schumukler, S. L. (2017). Innovative Experiences in Access to Finance: Market-Friendly Roles for the Visible Hand? The World Bank. Retrieved from https:// openknowledge.worldbank.org/ handle/10986/27529

10. Desta, N. T. (2015). Networking as a growth initiative for small and medium enterprises in South Africa (Doctoral dissertation). University of the Free State. 
Retrieved from http://scholar. ufs.ac.za:8080/bitstream/ handle/11660/2287/DestaNT. pdf? sequence $=1$ \&isAllowed $=y$

11. Distinguin, I., Rugemintwari, C., \& Tacneng, R. (2016). Can informal firms hurt registered SMEs' access to credit? World Development, 84, 18-40. Retrieved from https://ideas.repec.org/a/eee/ wdevel/v84y2016icp18-40.html

12. Esubalew, A. A., \& Raghurama, A. (2020). Commercial bank financing to micro, small, and medium enterprises (MSMEs): the mediating and multi-group effect analysis. Journal of Small Business \& Entrepreneurship, 1-29. Retrieved from https:// www.researchgate.net/publication/341916660_Commercial_bank_financing_to_micro_ small_and_medium_enterprises_MSMEs_the_mediating_and_ multi-group_effect_analysis

13. Hamburg, I., \& O'Brien, E. (2014). Using strategic learning for achieving growth in SMEs. Journal of information technology and application in education, 3(2), 77-83. Retrieved from https:// www.researchgate.net/publication/264256150_Using_Strategic_ Learning_for_Achieving_Growth_ in SMEs

14. Hoaglin, D. C. (2016).

Shortcomings of an approximate confidence interval for momentbased estimators of the betweenstudy variance in random-effects meta-analysis. Research Synthesis Methods, 7(4), 459-461. Retrieved from https://pubmed.ncbi.nlm.nih. gov/27231158/

15. Humavindu, M. N., \& Stage, J. (2015). Community-based wildlife management failing to link conservation and financial viability. Animal Conservation, 18(1), 4-13. Retrieved from https://www.researchgate.net/ publication/262492575_Community-based_wildlife_management_failing_to_link_conservation_and_financial_viability

16. International Monetary Fund (2019). World Economic Outlook Reports. Retrieved from https:// www.imf.org/en/Publications/
WEO (accessed on November 25, 2020).

17. Jaabi, S. A. (2018). SME Finance and Economic Development Paradox: The Case of Fish Industry in The Gambia. Advances in Social Sciences Research Journal, 5(9). Retrieved from https://www.researchgate.net/ publication/327647511_SME_Finance_and_Economic_Development_Paradox_The_Case_of_ Fish_Industry_in_The_Gambia

18. Johnstone-Robertson, J. M. (2017) Venture capital for biotechnology entrepreneurship in South Africa (Doctoral dissertation).

19. Jovanovic, B. 2019. The entrepreneurship premium. Small Business Economics, 53(3), 555568. Retrieved from https://link. springer.com/article/10.1007/ s11187-019-00234-w

20. Ketterer, J. A. (2017). Digital finance: New times, new challenges, new opportunities. IDB-Inter American Development Bank. Retrieved from https://publications.iadb.org/publications/ english/document/Digital-Finance-New-Times-New-Challenges-New-Opportunities.pdf

21. Kim, K. C., ElTarabishy, A., \& Bae, Z. T. (2018). Humane entrepreneurship: How focusing on people can drive a new era of wealth and quality job creation in a sustainable world. Journal of Small Business Management, 56, 10-29. https://doi.org/10.1111/ jsbm. 12431

22. Kimanzi, M. K., \& Gamede, V. W. (2020). Embracing the Role of Finance in Sustainability for SMEs. International Journal of Economics and Finance, 12(2), 453-468.

23. Kljucnikov, A., Belas, J., Kozubikova, L., \& Pasekova, P. (2016). The entrepreneurial perception of SME business environment quality in the Czech Republic. Journal of Competitiveness, 8(1), 66-78. Retrieved from https:// journals.indexcopernicus.com/ search/article? articleId $=675786$

24. Koleda, N., \& Oganisjana, K. (2015). Challenges in learning for company's financial viability assessment and management. Business: Theory and Practice, 16(2), 195-204. Retrieved from https://www.researchgate.net/ publication/303574712_Challenges_in_learning_for_company's_financial_viability_assessment_and_management

25. Langa, M. T., \& Govender, K. K. (2019). The Need for Agile Relationship Lending between Small Business and Banks, towards a More Engaged Relationship: A Case Study in Khayelitsha, South Africa. Asian Business Research Journal, 4, 29-34. Retrieved from https:// www.researchgate.net/publication/336117265_The_Need_for_ Agile_Relationship_Lending_between_Small_Business_and_ Banks_towards_a_More_Engaged_ Relationship_A_Case_Study_in_ Khayelitsha_South_Africa

26. Mbowe, W. E., Shirima, F. R., \& Kimolo, D. (2020). Role of Financial Innovation in Enhancing MSMES Access to Credit: An Empirical Investigation on Tanzania. Applied Economics and Finance, 7(3), 126-144. Retrieved from https://ideas. repec.org/a/rfa/aefinl/v7y2020i3p126-144.html

27. Musie, L. (2015). The use of financial literacy concepts by entrepreneurs in the small and medium enterprise sector in Mpumalanga Province (Doctoral dissertation). South Africa., University of Pretoria.

28. Nassr, I. K., \& Wehinger, G. (2016). Opportunities and limitations of public equity markets for SMEs. OECD Journal: Financial Market Trends, 1, 49-84. Retrieved from https://www.oecd-ilibrary.org/ finance-and-investment/opportunities-and-limitations-of-publicequity-markets-for-smes_fmt2015-5jrs051fvnjk

29. Olomi, D., Charles, G., \& Juma, N. (2018). An inclusive approach to regulating the second economy. Journal of Entrepreneurship in Emerging Economies. https://doi. org/10.1108/JEEE-08-2017-0056

30. Rahaman, M. A., Ali, M. J., Mamoon, Z. R., \& Al Asheq, 
A. (2020). Understanding the Entrepreneurial Intention in the Light of Contextual Factors: Gender Analysis. The Journal of Asian Finance, Economics, and Business, 7(9), 639-647. Retrieved from https://www.researchgate. net/publication/343916738_Understanding_the_Entrepreneurial_Intention_in_the_light_of_ Contextual_Factors_A_Gender_Analysis

31. Rankhumise, E. M., \& Letsoalo, M. E. (2019). Owners' Perspective of Factors Associated with Performance of Small, Medium and Micro Enterprises. International Journal of Entrepreneurship, 23(3), 1-17. Retrieved from https://www. abacademies.org/articles/ownersperspective-of-factors-associatedwith-performance-of-small-medium-and-micro-enterprises-8519. html

32. Rathnasiri, U. A. (2015). The Financial Management Practices of Small and Medium Enterprises in Sri Lanka. Global Journal of Contemporary Research in Accounting, Auditing and Business Ethics, 1(2), 374-401.

33. Registrar of Community Housing (2010). Financial Viability. Retrieved from https://www.rch. nsw.gov.au/reports/performancereports/fy-2012-1/nsw-tier-3-performance-report/tier-3-financialviability (Accessed 12 May 2020).

34. Rofiat, A. (2017). The effect of cashless banking on the financial performance of small and medium scale enterprises. International Journal of Advanced Research in Public Policy, Social Development and Enterprise Studies, 2(2), 133142. Retrieved from https:// www.semanticscholar.org/ paper/The-Effect-of-CashlessBanking-on-the-Financial-of-Rofiat/a042db6cdc950cdabc86c1d431f6096a013e5f99

35. Rosavina, M., Rahadi, R. A., Kitri, M. L., Nuraeni, S., \& Mayangsari, L. (2019). P2P lending adoption by SMEs in Indonesia. Qualitative Research in Financial Markets. https://doi.org/10.1108/QRFM09-2018-0103

36. Torrès, O., \& Thurik, R. (2019). Small business owners and health. Small Business Economics, 53(2), 311-321. Retrieved from https:// link.springer.com/article/10.1007/ s11187-018-0064-y

37. Trivedi, P. (2019). Determinants of SME Credit in MumbaiEmpirical Analysis on Factors. Journal of Developing Areas, 53(2). Retrieved from https:// ideas.repec.org/a/jda/journl/ vol.53year2019issue2pp194-203. html

38. Yeboah, M. (2020). US Small Businesses: A Quantitative Analysis of Working Capital Management and Profitability (Doctoral dissertation, Capella University). Retrieved from https://search. proquest.com/openview/2316db3 bf9e62f6f2abe2e7141fa6b3c/1?pqorigsite $=$ gscholar $\& \mathrm{cbl}=44156$ 